Article

\title{
The Redistribution of Representation through Participation: Participatory Budgeting in Chengdu and Delhi
}

\author{
Emilie Frenkiel ${ }^{1, *}$ and Stéphanie Tawa Lama-Rewal ${ }^{2}$ \\ ${ }^{1}$ Université Paris-Est Créteil, LIPHA, 94000 Créteil, France; E-Mail: emilie.frenkiel@u-pec.fr \\ ${ }^{2}$ Centre d'Etudes de l'Inde et de l'Asie du Sud, Centre National de la Recherche Scientifique, 75006 Paris, France; \\ E-Mail: tawalama@ehess.fr \\ * Corresponding author
}

Submitted: 30 March 2019 | Accepted: 26 July 2019 | Published: 24 September 2019

\begin{abstract}
A strong contention of the "representative turn" is that representation is consubstantial with politics (Saward, 2010). One way to test the heuristic value of this vision is to look for representation in an institution that was historically built against representation, namely participatory budgeting (PB), a democratic innovation that has spread globally with exceptional rapidity. The literature on PB identifies two types of relationships between participation and representation: (i) participation "challenges" (Houtzager \& Gurza Lavalle, 2009) existing forms and principles of representation (through "assumed representation" by civil society activists; or through "citizen agents"; Montambeault, 2016); or (ii) participation is "instrumentalised" (Fischer, 2012) by classic forms and actors of representation. On the basis of a comparative analysis of PB experiences in Chengdu (China) and Delhi (India), we argue in this article that a third type of relationship can be observed: participation-as implemented through $\mathrm{PB}$ - can also redistribute representation insofar as new, official representative roles are created. Moreover, looking at these new roles provides important clues about the principles of representation that are implemented and therefore about the transformative nature of PB.
\end{abstract}

\section{Keywords}

China; democracy; India; participation; participatory budgeting; representation

\section{Issue}

This article is part of the issue "Rethinking Representation: Representative Claims in Global Perspective", edited by Petra Guasti (Goethe University Frankfurt, Germany) and Brigitte Geissel (Goethe University Frankfurt, Germany).

(C) 2019 by the authors; licensee Cogitatio (Lisbon, Portugal). This article is licensed under a Creative Commons Attribution 4.0 International License (CC BY).

\section{Introduction}

One strong contention of the "representative turn" in political science is that representation is consubstantial with politics (Saward, 2010); in other words, "representation is everywhere" (Näsström, 2011, p. 508). In order to test the heuristic value of this vision, it seems interesting to look for representation in an institution that was historically built against representation, namely participatory budgeting (PB). PB is a participatory device that is meant to provide a necessary answer, a corrective, to the democratic deficit of representative democracy (Baiocchi \& Ganuza, 2014; Wampler, 2012a).

This democratic innovation was born in the Brazilian city of Porto Alegre in 1989. One finds "at its heart a rel- atively simple idea: citizens deciding over the priorities and projects that make up a public budget" (Baiocchi \& Ganuza, 2014). Basically, citizens and social organisations are provided a platform to discuss the priority of different projects and vote on the expenditure plan, which gives local citizens a voice over and the ability to supervise the proposed budgetary expenditure of the government, thereby in theory made more transparent, inclusive and responsible (Chen, 2007; Shah, 2007; Wampler, 2000).

This innovative, grassroots and democratic budgetary decision-making process has spread globally with exceptional rapidity: first to hundreds of municipalities in Brazil and other South American countries, then to thousands of cities on all continents since the 1990s (Sintomer, Herzberg, \& Allegretti, 2013), even though it 
remains today less developed in Asia than elsewhere. In this circulation process PB has undergone many adaptations, which have been closely observed by scholars. The first wave of studies on PB tended to focus on successful cases, investigating outcomes and contextual variations, and developing a comparative framework (Avritzer, 2006; Baiocchi, 2005; Santos, 1998; Sintomer et al., 2013; Sintomer, Herzberg, \& Röcke, 2008; Wampler, 2007). Later research tempered this enthusiasm by putting into perspective the dynamic implementation of $\mathrm{PB}$ in model cases like Porto Alegre with the weaker impact $P B$ has had on some municipalities where it was peripheral to city administrations; its outcomes were technically overdetermined; and the decision-making of participants was far removed from any locus of local power (He, 2011; Sintomer et al., 2008). Indeed a question that runs through much of this literature regards what is left of the initial radicalism of the Porto Alegre experience in its later avatars (Baiocchi \& Ganuza, 2014; Cabannes \& Lipietz, 2018; Wampler, 2012b). To what extent does PB remain, as in Porto Alegre, a transformative, empowering institution attached to the project of democratizing democracy? How far has it become, on the contrary, a managerial, communication-centred device compatible with neo-liberalism?

The relationship of PB with political representation is an important indicator of the direction taken. Indeed, the literature on PB suggests two possible relationships between participation and representation. A first scenario is that participation "challenges" existing forms and principles of representation (Houtzager \& Gurza Lavalle, 2009) through a new, "assumed representation" by civil society activists, but also by "citizen agents" (Montambeault, 2016). The second scenario is that participation is "instrumentalised" by classic actors of representation (Fischer, 2012, p. 18), starting with mayors and other local elected representatives; participatory devices such as PB then become political tools used by elected representatives to communicate about their action, and more generally to relegitimate themselves (Baiocchi \& Ganuza, 2014; Bherer, Fernández-Martínez, Espín, \& Sánchez, 2016). We argue in this article that a third type of relationship can exist. Indeed, our study of PB in Chengdu (China) and Delhi (India) leads us to observe that participation can also redistribute representation insofar as new, official representative roles are created; moreover, these new roles provide important clues about the principles of representation that are implemented in the PB process.

\section{Methods and Data}

The article offers a comparative analysis of two case studies conducted between 2014 and 2019 in Delhi and in
Chengdu. In both cities we collected data about the local PB process in order to answer two main, open questions: (i) How is PB-a global democratic innovationimplemented/interpreted/adapted in the particular context under study? And (ii) what forms of political representation can one observe in this process?

With regard to these questions, Chengdu and Delhi appeared as potentially "instructive cases" (Eckstein, 2009 , p. 139) for two main reasons. Firstly, as we said, they are among the rare examples of PB in Asia. Secondly, and more importantly, PB processes in Chengdu and Delhi can be a priori considered as "most contrasted" cases because they are embedded in very different political regimes: India and China have divergent theories and practices of political representation. Despite the illiberal turn taken with the coming to power of Narendra Modi's Bharatiya Janata Party (BJP) since 2014, India has so far remained a democracy built on competitive elections, relatively free media, an independent judiciary and an active civil society. On the Chinese side, although communist rule underwent great evolutions over the last 70 years, in this one-party system based on the concept of the Leninist vanguard party, political representation has invariably been defined by the Chinese Communist Party (CCP) as the capacity to represent the interest of the majority of the Chinese people (see Frenkiel \& Shpakovskaya, 2019). This exclusive "representative claim" (Saward, 2006) has considerably constrained pluralism, rule of law, freedom of speech and demonstration. The fact that Chengdu appears, as we will later see, as a clear case of "managerial" PB, while Delhi looks like a more "transformative" case, was congruent with this major contrast between the two political systems.

However, the "intimacy of analysis" (Tarrow, 2010, p. 243) that characterises case studies enabled us to see that in both Chengdu and Delhi the local political context is marked, for different reasons, by a de-emphasis on representation (something that is much more recent in Delhi ${ }^{1}$ than in Chengdu). To put it briefly, in Delhi PB was implemented by the AAP, a new party that was born from a strong critique of misrepresentation, and that placed the development of citizen's participation in decisionmaking at the centre of its political project. In Chengdu, like all over China, the CCP is still the sole representative claim maker and all other forms of representation are minimized or suppressed (Frenkiel \& Shpakovskaya, 2019). But the Party comprises 90 million members and 10 million civil servants (they do not necessarily belong to the Party but above county level, all leading cadres must be Party members) and the central leaders cannot afford to be held responsible for the misdeeds of lowerlevel leaders ${ }^{2}$. Its current strategy is to simultaneously put them in check by grassroots participation (direct elec-

\footnotetext{
${ }^{1}$ For an analysis of the exercise of power by the Aam Aadmi Party [AAP, Party of the Common Man] in Delhi, see Stéphanie Tawa Lama-Rewal, 2019.

2 To put it briefly, there are four administrative levels in China as provided in the Constitution: central, provincial, county/municipality and township/neighbourhood levels. The prefecture and the grassroots (village/community) levels are de facto but not de jure administrative divisions. Chengdu (prefecture) comprises 9 urban districts, 4 municipalities or county-level cities (shi), 6 counties (xian), 12 city divisions (shiqu), 317 townships and neighbourhoods (xiangzhen and jiedao) and 3432 villages and communities (cun and shequ).
} 
tion of village committees supplemented by PB and village councils in some places, among a broad array of devices), self-rule and CCP disciplinary commissions at central and lower levels. Therefore, our cases are not as "contrasted" as could be expected at first.

In terms of data, the article is based on two qualitative surveys, conducted between 2014 and 2019 in Delhi, and between 2016 and 2018 in Chengdu. In both places the unit of analysis was the PB process set up by regional authorities (i.e., the government of the National Capital Territory of Delhi and the prefecture-level government in Chengdu). We were interested both in the discourses justifying the interest of PB and in implementation processes-with specific attention being paid to the meetings that brought together citizens and authorities, i.e., to situations, and even to the scenography (when observable) of PB meetings. While the literature on PB has discussed the important implications of having physical versus online interactions during the PB process, our study suggests that the fact that physical interactions happen in public or in closed meetings also matters a lot. Thus, we conducted a series of interviews with local officials (i.e., elected representatives and functionaries of local administrations) and other participants in $\mathrm{PB}$, and we also tried to directly observe, as much as possible, local meetings.

In Delhi, 24 semi-directed interviews were done with cadres, elected representatives and volunteers of the AAP, as well as four interviews with NGO workers and four interviews with bureaucrats working for the citystate government. We could also directly observe two neighbourhood assemblies, and since such meetings are often video-recorded, we could analyse the videorecords of another five meetings.

In Chengdu, 23 semi-directed interviews were conducted with cadres of the United Front department (in Pengzhou and Chongzhou), village party secretaries, village representatives and local scholars consulted in the process. We could directly observe two village councils and read the minutes of previous councils on the village register as well as on official Internet portals whenever available. Finally, we used official documentation and media reports on PB in both cities.

In spite of important asymmetries between the PB experiences conducted in Delhi and Chengdu (see Table 1), we will show that a comparative analysis of these two case studies can be theory-building (Tarrow, 2010, p. 245). Indeed, our argument will outline two paradoxes. One, although political representation is de-emphasized in both cases, the very implementation process of PB actually generates new representative roles, i.e., "neighborhood assembly coordinators" in Delhi and "village representatives" in Chengdu. Two, in the Chinese, "good governance" kind of PB, "village representatives" challenge, even if implicitly, the dominant theory of representation; while in the Indian, "transformative" kind of PB, neighborhood assembly coordinators are actually delegated representatives who implicitly re-affirm elections as the main source of democratic legitimacy. The article will show, therefore, that the forms and principles of representation observed in PB processes complicate their qualification along the radical/neo-liberal axis and constitute important criteria to assess the transformative nature of PB.

The first section of the article presents the main features of the two PB experiences under study. In the second section we argue that despite the clear asymmetry between Chengdu and Delhi, the two cases present important similarities regarding (i) the justification of $\mathrm{PB}$, and (ii) the creation of new, official representative roles. The third section focuses on contrasts between the two experiences in terms of the place of procedures and symbols; it then argues that although processes and situations are different, they give way in both cases to a redistribution of political representation, and to some extent to its redefinition.

\section{PB in Chengdu and Delhi: Two Significant but Asymmetric Experiments}

Neither the Chengdu nor the Delhi PB are representative of a national tendency. In China, the Brazilian idea of PB was formally introduced in the context of campaigns to open budgets since the 1990s, at a time of budgetary reforms aimed at efficiency and accountability through central and social control (Ma, 2009). In 2005, it was practiced for the first time in Wenling, Zhejiang province. Different townships experimented differently. While PB was introduced in Xinhe as a reform to promote the role of the legislative branch in budgetary decision-making and encourage citizen participation in congress deliberations, in Zeguo, it took the form of deliberative polling. PB was primarily focused on empowering citizens, rather than the People's Congress, to make budgetary decisions on capital projects (Fewsmith, 2013; Fishkin, He, Luskin, \& Siu, 2010; He, 2011; He \& Thogersen, 2010; Li, 2005; $\mathrm{Ma}, 2009)$. The pioneering introduction of PB has significantly evolved and has considerably but unequally expanded since 2005. The experiences conducted there have remained exceptional even though they have been known and emulated all over the country. Only a few other experiments have led to stable practice, such as Wuxi, where, since 2006, resident representatives select and prioritize among capital budget programs planned by the government (Wu \& Wang, 2011) and Chengdu, since 2009 (Ming, 2014).

In India, a few experiences with PB did take place before the Delhi janta ka budget (people's budget). The most ambitious one was the "People's Plan campaign", implemented from 1996 onwards in the rural areas of the southern state of Kerala (Heller \& Isaac, 2003) by a coalition led by the Communist Party of India (Marxist)-which however much weakened after four years (Tharakan, 2005). In the southern city of Bangalore, a civil society organisation, Janaagraha, organised a micro local version of PB in a selection of municipal wards in 
2001, but again the experience was short lived and could not be continued, let alone scaled up. Only the municipality of Pune, on the Western coast, managed to sustain an initiative put in place in 2006, but this experiment with PB has largely been limited to a collection of people's demands through the filling of forms.

The two cases under study are therefore neither unique nor representative, but they are significant in their respective national context, for different reasons. Chengdu's PB has proved to be durable and stabilized, while Delhi's experience, although short-lived, has been remarkable for its radicalism and visibility.

Indeed, the PB scheme taking place in Chengdu's village councils, (yishihui, literally, meetings where rural inhabitants discuss official business, including budget issues but not only), is an interesting case because of its scale, design standardization and institutionalization. The peculiarity of Chengdu's village governance also rests on some transfer of power from the elected village committee (cunmin weiyuanhui) to the elected village council, turned into a regular oversight and decisionmaking institution addressing significant issues such as how to use collective assets, allocate available financial resources, and set the boundaries of agricultural land on which households have use rights (village committees are elected and have executive power to handle village affairs. In places like Chengdu where the village council, also translated as "village representative assembly" is institutionalized and regularly convened, oversight and horizontal accountability of elected village leaders improve significantly).

These local meetings are organized to discuss village projects, which have been made transparent and open to deliberation within the framework of village councils gathering, once a month, local "representatives" (daibiao) elected for this purpose. These meetings were first sparsely organized for farmers to discuss land issues, after the reform in land rights triggered by the Property Law of 2007 and the severe and unsolvable conflicts it led to. Moreover, after the devastating 2008 Wenchuan earthquake, such deliberative platforms were all the more needed to discuss reconstruction. Their embryonic form originated in Mayan village, Qionglai county, where trusted residents, knowledgeable, skillful senior villagers, party members, former village and local leaders who still inhabited the villages, were invited to discuss and decide land rights issues.

In 2009, former Party secretary of Sichuan province Li Chuncheng decided to formally introduce PB in villages with the help of scholars like Li Ling (Sichuan Academy of Social Sciences). A regular platform was needed to discuss budgets and projects after the 2008 earthquake, as well as to alleviate citizen discontent with local officials, which slowed down policy implementation and led to shangfang (petition and complaints) and protests that spiked with the 2007 Property law ${ }^{3}$. To break down the dual economy (i.e., the gap between rural and urban development), Chengdu, which was designated "pilot city" in 2003 , created a single regional plan for public services covering the entire Chengdu region. The plan prioritizes rural infrastructures and the equalization of public services between rural, peri-urban, and urban areas based on a public fiscal system providing enough financial resources, especially in rural Chengdu. What we call PB in this article therefore refers to the significant budget allocated since late 2008 by Chengdu prefecture for the improvement of village-level public services, called "Village Level Public Services and Social Administration Funding". The process is rarely referred to as PB (canyushi yusuan) in Chengdu. Chengdu's prefecture-level government directly shares revenue with villages, which in 2009 received at least 200,000 RMB (32,000 USD) (Ming, 2014) ${ }^{4}$. Since its implementation ten years ago, the funding has first doubled, then tripled. Besides, if local authorities (at township or higher level) plan and implement the majority of rural investment, 8 out of the 59 rural public services classified by the Chengdu government are delivered by local villages whose residents are required to participate directly in their local public decisions and services. Over the first three PB cycles, PB funded nearly 40,000 projects decided by local residents and implemented in over 2,300 villages. The per capita annual amount debated was around 22 USD, which ranks quite high in world comparisons and is probably equivalent or slightly higher nowadays.

Villages experimented in various ways with PB until the process was strictly stabilized and institutionalized under the "deliberation and social dialogue system" in Pengzhou, a 1.2 million-inhabitant municipality located north of Chengdu, where the recent urbanization and pluralisation of interests, the fast sale of collective rural land as well as polluting petrochemical industry triggered conflicts. Having the pioneer experiments in Wenling, which lacked institutional stability, in mind, local leaders and scholars decided to coordinate the process more strictly with the township level and the people's congress so as to write it into the local law. As this is highly uncommon, it drew the attention of senior leaders and scholars and was spread to the whole Chengdu region after the 18 th central party congress (2013), which endorsed popular participation.

In Delhi, PB was introduced for the first time in 2015, shortly after the AAP won regional elections with a historic score (67 seats out of a total of 70). PB occupied an important place in the discourse of the newly elected party. Organising assemblies (sabhas) open to everyone, at the truly local level of the neighborhood (mohalla), where priorities regarding local services and infrastructures could be collectively identified, and where the work done by local authorities could be monitored, was pre-

\footnotetext{
${ }^{3}$ The reform maintained state ownership over land but gave individual use rights the same level of protection as afforded state and collective rights.

${ }^{4}$ This amount has increased every year. It amounted to 47,500 USD in 2011 and 50,000 USD (with a maximum of 85,000 USD) in 2012 (Ming, 2014). More recently, allocated budgets have hovered between 400,000 RMB and 800,000 RMB (58,500 USD-115,000 USD).
} 
sented as giving substance to a notion that was central in the party's discourse, namely "self-rule" (Swaraj). PB was meant to demonstrate the party's seriousness when it came to the two main ideas around which it was formed: (i) the need to fight political and bureaucratic corruption by developing transparency and accountability; (ii) the imperative to make democracy more participatory through decentralisation and the institutionalization of various devices making it possible for people to take part in decision-making. All this was expected to make governance at the same time more democratic and more efficient.

Therefore, when PB was implemented in the Spring of 2015, this was done with much fanfare, the mobilisation of all state resources and the strong involvement of the party's top leaders. However, it was decided that implementation would proceed in two phases: there would first be a pilot experiment on a sample of 11 constituencies (all of them having elected an AAP representative); and on the basis of that experiment, the "people's budget" would take place all over Delhi the following year.

We will here focus on neighbourhood assemblies (mohalla sabhas), which are the most visible and arguably the most significant moment of the PB process in terms of political representation. Some 400 such assemblies were organised in April-May 2015, most often in local schools. Typically, these assemblies would involve local residents, functionaries representing the various departments in charge of local services and infrastructures (water, public works, horticulture, etc.), the locally elected Member of the Legislative Assembly (MLA), and two party volunteers nominated by him/her, and called "mohalla sabha coordinators".

In terms of budget, it was proposed in the pilot phase that each neighbourhood assembly would be entitled to deal with five million rupees every year. This amount appears rather modest, since altogether it makes up less than $1 \%$ of the overall budget of the city-state of Delhi ${ }^{5}$; yet this is a budget that makes it possible to construct or improve urban infrastructures on a scale that can have a real impact on the life of (poor) local residents, as for example when public toilets, street lighting or sport equipment are concerned.

In Delhi, the outcome of the "peoples' budget" was a mixed one. Participation in neighbourhood assemblies was much weaker than expected (the average number of participants was around 80 persons, out of about 4,500 local residents); and the selection of priority work was not prepared through prior discussions (Rao, 2016). Moreover, because Delhi's governance is especially complex (many types of works do not depend on the Delhi government), people often suggested works on which the Delhi government requires the cooperation of other local authorities, such as municipal bodies or the parastatal agencies depending on the Central government. Such cooperation however was not forthcoming, and it generated a loss of credibility both for elected representatives and for neighborhood assembly coordinators.

The party's response was to act on the weaknesses identified during the pilot experiment. From the Fall 2015 onwards, cadres organised the nomination and training of about 6,000 assembly coordinators as well as the mapping of infrastructures present in every neighbourhood. Simultaneously, they started preparing a mobile application that would allow coordinators to immediately identify the department and official in charge of such or such local amenity, in view of arming them for the second phase of PB.

However, the second phase never happened. The government of the city-state had always been a weak one; but by mid-2015, tensions between the Delhi government and the Central government (dominated by the BJP, a Hindu nationalist party) developed into a fullfledged institutional tussle that ultimately resulted in the paralysis of the former. As a result, the Swaraj Bill, a crucial piece of legislation meant to institutionalize neighbourhood assemblies and PB, was never notified, and the whole process was suspended indefinitely. The team of cadres in charge of PB then decided to refocus their energies on the education sector, and more precisely on School Management Committees' mahasabhas (super assemblies). Thus, organisational learning was deviated onto another participatory scheme, focusing on government schools ${ }^{6}$.

The fact that the PB process was not repeated after the first year clearly makes Delhi a limit case if we consider the defining criteria of PB proposed by Sintomer, Herzberg and Allegretti (2013), namely that (i) discussions focus on financial/budgetary processes; (ii) the city level, or a (decentralized) district with an elected body and some power over administration and resources is involved; (iii) the process is repeated over years; (iv) some form of public deliberation is included within the framework of specific meetings/forums; and ( $v$ ) some accountability is required so that the output reflects the public will (Sintomer et al., 2013, p. 11). Yet since the Delhi PB was meant to be repeated, and since it found a new expression around the school management committees, we will consider it as a real, if failed, case of PB.

As regards $\mathrm{PB}$ in Chengdu, all but criterion (ii) are met, which does not invalidate its classification as PB given the relative decentralization of the Chinese administration and autonomy of villages, the size of the affected populations (Chinese villages would demographically qualify

\footnotetext{
${ }^{5}$ In the Indian constitutional architecture Delhi has a specific status: since the adoption of the 69th Constitutional Amendment Act in 1991, Delhi has been a "quasi-state", officially called the National Capital Territory of Delhi (NCTD). Like the other 29 states of the Union, the NCTD has its own legislative assembly and government, but this government is weak because it has no control over three domains that, in this particular case, pertain to the Central government, namely land development, police, and law and order. Delhi is therefore a city-state, and its Chief minister is closer to a city-manager; yet the centrality of Delhi in India's political life confers disproportionate media attention to what its government says and does.

6 In the typology of PB proposed by Cabannes and Lipietz (2018), SMC mahasabhas would arguably qualify as "thematic", "actor based" PB (as opposed to territorially based).
} 
Table 1. Basic features of PB in Chengdu and Delhi.

\begin{tabular}{lll}
\hline & Chengdu & Delhi \\
\hline Population & 16 million & 17 million \\
\hline Urban/rural & $70 \%$ urban & Mostly urban \\
\hline Key institution for PB & $\begin{array}{l}\text { Yishihui (village council and urban } \\
\text { community council) }\end{array}$ & Mohalla sabha (neighbourhood assembly) \\
\hline Participants & $\begin{array}{l}\text { Residents elected for three years; village party } \\
\text { secretary; sometimes bureaucrats }\end{array}$ & $\begin{array}{l}\text { Voters of the neighbourhood; mohalla sabha } \\
\text { coordinators; (sometimes) locally elected MLAs; } \\
\text { bureaucrats from the concerned departments }\end{array}$ \\
\hline Dates & 2008-now & 2015-2016 \\
\hline Eligible projects & Basic services and infrastructure; training; & $\begin{array}{l}\text { Basic services and infrastructure (footpaths, } \\
\text { sewers, parks, public lighting...) }\end{array}$ \\
\hline
\end{tabular}

as cities in many countries) and the financial significance of the allocated budget.

Table 1 highlights the many asymmetries between the two experiments under study: in their magnitude, degree of institutionalization, engineering, domains of intervention, and also in the interest they have evoked. One must note, among the many contrasts, the fact that PB meetings are closed in Chengdu (only the minutes are available), whereas they are public in Delhi. This fact will prove important regarding the type of representation generated by such meetings, as we shall see.

\section{A Common Democratic and Managerial Promise}

Despite the contrasts highlighted above, the two experiences conducted in Delhi and Chengdu also have a lot in common: they combine, like many cases of PB elsewhere, a "democratic promise" (Cabannes \& Lipietz, 2018) with a managerial one-although in different proportions. Indeed, in both cases PB is presented, in the discourse of the organizing party, as a means to associate citizens to decisions that concern them, but also as a way to fight corruption. In other words, PB is supposed to make decision-making at the local level more democratic and more efficient at the same time.

The Chengdu experience highlights the place of democracy in Chinese political discourse. Electoral democracy's expansion has been blocked beyond grassroots level. Its most daring experimentation was located in Buyun township, also located in Sichuan province. In Chengdu, the yishihui is officially associated with "consultative democracy" (xieshang minzhu, also strategically but confusingly translated as deliberative democracy) and public participation (gonggong canyu). Consultative democracy is officially defined as a democratic pattern in which, led by the CCP, all sections of society are consulted on major issues before and during policy-making processes. This notion has been more abundantly resorted to since 2012 to justify the Party's claim to represent the whole of the Chinese people. In order to represent such a diverse and large population (and now officially recognized as such), the Party must not only organize consultation of the eight authorized non-communist parties (especially thanks to institutions such as the United Front ${ }^{7}$ ), diverse political, economic, academic elites ${ }^{8}$ but also the common people. Consultation is more encouraged than previously in national and local congresses and in the political consultative conference system, but a new stress is especially put on consulting grassroots organizations and organizing debates at the grassroots level.

The monthly meetings organized in Chengdu are local interpretations of these central orientations. As one council representative explains, yishihui are "meetings representing the views of the masses because they serve as a bridge for the bottom and the top to communicate" (Interview with yishihui representative, Chengdu, July 2016). They offer a platform for village representatives to express their neighbours' views and get involved in the decision-making process. In both official and informal discourse, representation is de-emphasized. The yishihui participants are designated as yishihui representatives (daibiao), participants (canyuzhe) or members (chengyuan) but it is striking that representation is more often than not completely erased as participants are equalled with masses (qunzhong), residents (cunmin, jumin), peasants (nongmin) or common people (laobaixing) and more rarely with citizens (gongmin). Representation in this case seems to pertain to identity or embodiment representation ("acting as"), whereby the relation of representation is supposed to be based on an immediate community of interests, opinions, beliefs and often identity between the representative and

\footnotetext{
${ }^{7}$ The United Front work department is a CCP agency created during the civil war (1945-1949) and reestablished under Deng Xiaoping which is in charge of managing relations with the non-Communist Party elite (including the eight minor parties, individuals and organizations holding social, commercial, or academic influence, or who represent important interest groups, both inside and outside China). Its shrinking role is currently being redefined but there are still branches at all administrative levels to guarantee CCP oversight over groups that are not directly associated with the Party and government.

8 Jiang Zemin's "Three Represents" theory, ratified at the 16th Party Congress in 2002 reflects the CCP's attempt to adapt to the new realities and represent new social groups such as entrepreneurs and intellectuals.
} 
the represented, more than the expression of consent. (Sintomer, 2013). Identity representation appears to confer more legitimacy to yishihui representatives than the fact that they have been elected by villagers.

Yishihui meetings aim at reducing the tensions and conflicts rising at the most grassroots level ("nipping them in the bud") through empowering common citizens to have a say in local budgets and supervising official practice. They are designed to limit corruption and restore public trust in authorities through making local investments, supposed to further economic development and reduce inequalities (especially rural vs. urban), more transparent and collectively debated. With these meetings, common citizens are expected to "decide" (jueding, shuo le suan) and "solve their problems among themselves" while the role of elected village committee members and selected members of the party branch is reduced to convening and moderating the meetings as well as taking stock of the decisions and reporting them to higher authorities and higher cadres and bureaucrats, who attend only if and when invited by the councils. The real objective of institutionalizing these oversight assemblies is to reduce social instability and conflicts and therefore complaint and petitioning through boosting self-governing and autonomy at the village and community level, and compelling the village committee as well as local officials to be more transparent, efficient and accountable.

Since in China local congress representatives (renda daibiao) are often devoid of power, and local congresses are rubber stamp institutions representing the Party more than citizens, local cadres are powerful but disconnected from popular needs. The absence of electoral representation entices them to respond above all to higher authorities and promotional standards. Besides, it does not prevent corruption by personal, family, clanic, private interests. Village councils have the potential to give more clout to these local congresses especially regarding budget issues, forcing local officials to respond to the actual needs of the local population, and also give them arguments to reject extravagant (called "face projects") or disconnected projects imposed by their hierarchy.

Leaders (village committee members, village party secretary and indirectly county officials) undeniably lose a great part of their discretionary powers by "letting masses decide for themselves" but according to local scholars like Li Ling (personal communication, October, 2016), a broad consensus exists among officials at various administrative levels because PB in the form of the yishihui has proven to be an efficient governance instrument in all these respects, and it is also conceived as cultivating the competence of citizens, who are made to understand the complexity of policy-making and better comply with government decisions. The discourse on PB in Chengdu therefore invokes both democracy and good governance as PB appears as a managerial device aiming at efficient governance through popular participation and oversight.
In Delhi, like in Chengdu, corruption is a central theme that connects the democratic and the managerial promises of PB. Indeed, the AAP was born from the "India Against Corruption" movement that shook the country's large cities in 2011-2012 (see Chowdhury, 2019). Thus, PB is presented as a means to correct the misrepresentation of people's "true interests", misrepresentation being caused by the fact that decision-making happens in closed-door meetings, among people disconnected from ground realities and indulging in corruption. It is proposed that PB, i.e., the direct involvement of lay citizens in decisions concerning local affairs, will bring efficiency, as it will both decrease corruption and improve the adequacy of decisions to real needs.

But if the anti-corruption theme is a strong link between our two cases, the discourse justifying PB is very different in Delhi with regard to (i) the type of democracy envisioned and (ii) the political function of $\mathrm{PB}$ for the party. Indeed, in contrast with "consultative democracy" in China, "participatory democracy" in the AAP's discourse signals the party's radicalism in two senses: firstly, participation is presented as a major way to transform politics, to "change the rules", to "reverse the governance process" (Interview with AAP cadre, Delhi, 2017); secondly, it signals a will to return to the sources of Indian democracy, identified with Gandhi's political thought. The neighbourhood assemblies experimented with and theorized by the leaders of the AAP can indeed be seen as the contemporary version of the "little republics" celebrated by Gandhi in the 1930s (Tawa LamaRewal, 2018b).

An analysis of the discourse of the AAP-as observable through its manifestoes, leaders' public speeches but also interviews with cadres, elected representatives and volunteers - helps understanding how participation is conceived by the party. It reveals that the notion of participation encompasses several ideasincluding communication, consultation, discussion and education-but that two aspects clearly dominate, namely action/decision-making and control/surveillance (of public authorities). On the whole there is little emphasis on discussion and debate, and no mention at all of deliberation. A formula often used by party leaders Arvind Kejriwal and Manish Sisodia while they were introducing the concept of PB in the first neighbourhood assemblies organized in May 2015 sums up this emphasis: "don't say/think 'our government'; say/think 'we, the government"' (hamara sarkar nahi, ham sarkar). This formula is typical of the de-emphasis (sometimes verging on the denial) of the role of representatives in the AAP's discourse (Tawa Lama-Rewal, 2019): we are told that "elected representatives will implement people's decision" (AAP, 2014); that people will be the government.

One can read this injunction as an expression of the fundamentals of the party, that reflect the trajectory of its leaders, from anti-corruption activists to movement organizers to party founders: if mohalla sabhas are meant, explicitly, to improve local governance by associ- 
ating local people to decisions regarding their own neighbourhood, these are also, in a more implicit but equally important manner, a mode of mobilization that aims at putting constant pressure on local authorities. Thus, in Delhi, PB is far from evoking a consensus among government functionaries. In this respect, the few interviews we could conduct (since bureaucrats are most often very reluctant to give their opinion on policy issues) suggested that at least two visions co-exist. At first, a mildly positive one was expressed by top-level civil servants (possibly because these are more mindful of their duty to follow orders). This first vision emphasized the benefits of PB in terms of educating all stakeholders: PB, they said, made bureaucrats more aware of local needs, and people more aware of the intricacies of local governance. In this vision, PB was a good initiative because it made local governance more responsive to people's needs. But another, more negative vision was expressed by junior bureaucrats. They underlined the burden, for them, of having to work extra-hours to interact with people who have no idea of the complexities of Delhi's governance. And above all, they resented having to bear the brunt of people's anger, in a context where residents, being gathered as a collective, felt emboldened to criticize the administration's work. Indeed, neighbourhood assemblies did force them to face the people as representatives of the state; or at least of its administration.

Both our cases therefore seem to illustrate how the democratic dimension of PB can be mitigated by its instrumentalization for managerial purposes. PB nonetheless redefines and redistributes representation.

\section{The Paradoxical Emergence of New Forms of Representation}

Shifting the focus of investigation from discourses to practices reveals that the "democratic promise" of PB is realized in Chengdu mostly through strong procedures, and in Delhi (where procedures are weak) mostly through symbolism. Indeed, our close study of processes, and more precisely our interest in the political significance of the format of meetings in the two cities led us to observe (i) that PB processes favour the emergence of new, official types of representatives; and (ii) that these representatives implicitly convey ideas on political representation that are not necessarily congruent with the dominant discourse (i.e., that of the CCP in Chengdu; that of the AAP in Delhi).

Contrary to Delhi, not everyone participates in PB meetings in Chengdu, where a new layer of representatives is created: they are local residents, supposed to represent their neighbours, but they are expected to be endowed with special skills, which blends conceptions of representation as description and distinction (Sintomer, 2013). Representatives are also expected to express themselves well, understand both their neighbours and party cadres, and therefore to be proper mediators. Following very detailed instructions, village repre- sentatives are encouraged to consult their limited constituency of neighbours, concoct and propose projects they feel strongly about, and pass on information on new policies as well as the sense that the CCP cares for their needs and is responsive. The standardization of yishihui, where budget and other important issues are collectively discussed and supervised, therefore amounts to substantial change as these meetings beef up the role of village representatives (yishihui participants) while limiting that of village committee members-who, although elected by universal suffrage, do not meet very often, are quite weak, and often find it difficult to override or constrain the power of the appointed village party secretary. According to the communicating vessels principle, the regularly convened and tightly organized yishihui allows participants to finally gain some of the former power of the village party secretary (also called yibashou, "the number one guy") who tended to hold on to his/her traditional monopolistic power and make budget decisions in all discretion, and even alleviate some of their dependence on township authorities which many village committees could not overcome. However, these residents among residents are legitimized by their neighbours' votes, which give them the mandate to meet every month, make important decisions and substantially represent their interests. They constantly interact and respond to their constituents-neighbours which they embody (thus explaining why they are often called "residents"), and their role is conceived as a mere conveyance of views and projects - as skilled and selected mediators voicing their neighbours' grievances and expectations in an audible (understandable, articulate and "civilized") manner. Village representatives can therefore be said to be endowed with a triple legitimacy (identity, procedural and performance).

This is changing the traditional Leninist and Maoist pattern of representation where the avant-garde constituted by CCP cadres is indispensable to the expression of the masses' interests as the latter, even though sovereign, are not fully able to understand and express them themselves without the former. Chengdu yishihui guidelines however stipulate that there cannot be too many party members involved. We may therefore wonder if this Chengdu innovation is a small but decisive step in the gradual formation of capable citizens finally able to express themselves without the filter of the Party.

In Delhi, the new representatives officially created by and for the implementation PB in 2015 were the neighbourhood assembly coordinators. In order to organise meetings in each neighbourhood, two "mohalla sabha coordinators" were nominated by the locally elected representative, the MLA. Their role was, before the meeting of the mohalla sabha, to inform local people and encourage them to participate; during the meeting they had to moderate discussions between residents, but also between residents and bureaucrats representing the various concerned departments (in charge of water, horticulture, roads, etc.); and after the meeting they were 
in charge of following up and making sure that departments were working as per the priorities identified by the mohalla sabha. These coordinators were always party volunteers; according to AAP cadres, the idea was to have one male and one female coordinator in each neighbourhood, but our investigations suggest that women coordinators were very few.

Mohalla sabha coordinators (now called "MLA representatives" in the more recent context of School Management Committees mahasabhas), being nominated by the MLA, really are delegated representatives; as such they have no autonomy vis-à-vis the locally elected representative; they are therefore not in a position to alter power equations. In any case, since the "people's budget", as we saw, was stopped in its tracks after only one year by the Central government, these coordinators had no opportunity to build on their new status.

However short their existence, it is worth noting that the legitimacy of mohalla sabha coordinators as representatives derives, although indirectly, from the MLA's electoral legitimacy. Indeed, the whole modus operandi of PB in Delhi suggests that notwithstanding the AAP's deemphasis on representation, the legitimacy offered by elections remains central for the party. Neighbourhood assemblies are organized around the local elected representative (whether $\mathrm{s} /$ he is present in person or through her/his nominees, the assembly coordinators), and several aspects of the procedure implicitly refer to the principles of representative democracy. For instance, in order to be allowed to participate in a neighbourhood assembly, one must prove that one is a voter registered in the local polling booth; therefore "local people" are in effect defined not as residents but as voters. Also, the notion of democratic decision-making is reduced to a very basic procedure of hand vote: the moderator of the assembly will read aloud all the suggestions put forth by participants, who are then invited to raise their hand whenever they support a suggestion; the prioritization of local works to be done is based on counting the raised hands. The pilot version of PB therefore manifests a rather simplistic vision of what makes for democratic, participatory decision-making ${ }^{9}$.

Thus, the observation of PB processes in Delhi suggests two interesting contrasts with Chengdu. The first contrast is that the procedural dimension of participation is much less developed in the Indian capital city-indeed it is much less developed than for (electoral) representation. The concrete organisation of elections in India reflects the State's old and deep concern with issues of freedom, fairness, and representativeness (Bajpai, 2016; Jayal, 2016; Shani, 2018). By contrast, the organisation of participatory spaces is often shallow. Mohalla sabhas are one of the most ambitious experiences in participatory democracy in the country, and yet, as we saw, they did not have much to offer in terms of training participants or organising discussions.

But if mohalla sabhas are weak in terms of procedure, they are strong in terms of symbolism - this is a second contrast with Chengdu's yishihui. Interviews with AAP cadres involved in the organisation of PB reveal a strong awareness of the importance of symbols for citizenship building (Goetz \& Jenkins, 2005; Nez, 2016; Tawa Lama-Rewal, 2018b), in a context where bureaucrats are not used to being accountable to ordinary citizens. These cadres explained that there is a "message" involved in the role played by the elected representative-or his/her nominees-in the assemblies: the presence, in person or by proxy, of the elected representative clearly signifies that the party in power at the state level (the AAP) is serious about this new process, which emboldens "the common man" to actually address these "big people".

Indeed, the fact that neighbourhood assemblies are public meetings-that is, meetings in which all locally registered voters can participate, but also meetings that can be observed by anyone, including the press-is significant regarding the question of political representation. Critics of the AAP have argued that these assemblies' main objective is actually to enable the party's elected representatives to put on a show, to play the role of the honest, devoted keepers of public interest vis $a$ vis the administration. The impatience with which the newly elected government set up the "people's budget" certainly does suggest that one important concern was to make the party's commitment to decentralization and participation visible. But the importance of visibility is not necessarily limited to electoral calculations. The mise en scene specific to neighbourhood assemblies arguably makes not only the party, but also "the people" and "the state" visible to each other in a new manner. In other words, the public character of neighbourhood assemblies generates passive symbolic representation ${ }^{10}$ in two ways: firstly, it forces onto participating bureaucrats the role of representative of not only their specific department, but more generally-and symbolically-the state. And secondly, it attributes to the few dozens of voters who happen to participate in each mohalla sabha the role of representing "the (local) people". Even though India's political life is replete with crowds who protest, demonstrate or sit in the public space, such crowds, through their spokespersons, usually address an absentee state. And even though administrative offices are open to the public, the public in these places usually is

\footnotetext{
${ }^{9}$ However, interviews with party cadres reveal that this hurried aspect of the experiment was later regretted, and that rethinking was going on regarding possible ways to organize a collective discussion before the assembly, so as to provide participants with enough information and time to produce better choices.

${ }^{10}$ Symbolic representation happens whenever the mere presence of one or several persons in a political context signifies that of a larger group, or of an abstract entity; it is a more or less implicit way of "standing for" someone or something beyond oneself. The scholarship on symbolic representation (for instance Hayat, Péneau, \& Sintomer, 2018; Pitkin, 1967) mostly focuses on active symbolic representation (for instance, the representation of "women" by a female Minister, of "the nation" by the king, or of "the people" by a group of demonstrators), but it is important to note that symbolic representation can also be passive, as in the case of bureaucrats participating in neighbourhood assemblies in Delhi.
} 
made up of individuals, or at most a few members of the same family. The staging of an exchange, in the public space, between "the people" and "the state" is on the whole a rarity. Thus, if neighbourhood assemblies offer AAP elected representatives an opportunity for a (theatrical) performance of "giving power back to the people", they also constitute a political performance with real didactic potential-on the condition, of course, that such assemblies are organised on a regular basis, and that they have concrete, visible outcomes.

In terms of political representation therefore, one can identify two main outcomes of Delhi's "people's budget". Firstly, the formal nomination of neighbourhood assembly coordinators by AAP elected representatives manifests the tentative institutionalization of a new, delegated type of representative. Secondly, the public character of neighbourhood assemblies, and their mise en scene inspired from the "public hearings" organised by civil society organisations (Tawa Lama-Rewal, 2018a), also favours a symbolic type of representation (Saward, 2010).

\section{Conclusion}

The selection of Chengdu and Delhi as cases studies of the relationship of PB with political representation contributes to documenting the recent implementation of this global democratic innovation in the Asian continent. More importantly, it provides a heuristic contrast between a "managerial" type of PB, strong on procedures but deprived of symbolism (Chengdu), and a "democratic" type, strong on symbolism but weak on procedures (Delhi). Contrary to expectations, we find that procedures in Chengdu actually challenge the locally dominant definition of political representation, and that for all its symbolism, PB in Delhi ultimately reaffirms a classic definition of political representation as based on elections.

More precisely, our analysis of PB in Chengdu and Delhi reveals that this participatory device, promoted in a political discourse that de-emphasises representation, actually generates new forms of representation; indeed, it redistributes representation and it redefines it at the same time.

In both our cases, PB redistributes representation: it leads to the emergence of new representatives, besides the usual, "official" ones (party secretaries and elected village committees in Chengdu, MLAs in Delhi): both village representatives and mohalla sabha coordinators do claim, more or less explicitly, to "speak for" local citizens and to "stand for" local interests, to paraphrase Hanna Pitkin (1967).

In this process, political representation is redefined. In Chengdu, village representatives are endowed with a triple legitimacy (procedural, identity and performance). They are legitimized by the mandate they receive from their neighbours to meet every month, make important decisions and substantially represent their interests. They are also legitimate as they act as villagers and embody residents when they make decisions regarding vil- lage investments but also land issues. In Delhi, the nomination of assembly coordinators (who will be called "MLA representatives" in the later participatory device of school management committees) by elected representatives (the MLAs) amounts to creating delegated representatives; while the mise en scene of meetings imposes a passive, symbolic type of representation onto bureaucrats and lay participants.

But does this challenge the larger political system? How far can such redistribution go, considering that PB is in both cases organised and controlled by the party in power (at least at the local level)? Are village representatives and mohalla sabha coordinators more than an extension of CCP cadres and AAP MLAs? More largely, what is the significance of our observations, beyond the somewhat limited perimeter of PB?

In Chengdu, the existence and action of village representatives de facto constitute a breach in the CCP's monopoly of political representation as it constrains the role of the village party branch and the influence of higher party cadres on it, as well as on the elected village committee. It also seems to signal a step forward in the training of capable citizens finally able to express themselves without the filter of the avant-garde Party. However, this has very limited consequences on the system of representation because these decisions are circumscribed to the village-level without any impact on the larger scale and more significant projects and policies. In Delhi, the significance of PB lies not so much in the (limited) role played by delegated representatives as in the public, confrontational dimension of interactions between those who claim to represent the people (i.e., the MLA and his/her nominees) and bureaucrats, cast in the new role of "representatives of the State". Our comparative analysis therefore suggests that the forms and principles of political representation observed in PB processes constitute relevant and significant criteria to assess the transformative nature of PB.

\section{Acknowledgments}

This research is part of a collective research project jointly funded by ANR and DFG, called CLAIMS (https:// claims.hypotheses.org/68); it greatly benefited from discussions within the team. Special thanks are due to Yves Sintomer and Debora Rezende for their comments on an earlier version of this article. We also want to thank the two anonymous reviewers as well as Brigitte Geissel and Petra Guasti for their insightful critiques and suggestions.

\section{Conflict of Interests}

The authors declare no conflict of interests.

\section{References}

Aam Aadmi Party. (2014). Aam Aadmi Party: National manifesto 2014. Aam Aadmi Party. Retrieved 
from https://aamaadmiparty.wordpress.com/2014/ 04/03/aam-aadmi-party-national-manifesto-2014

Avritzer, L. (2006). New public spheres in Brazil: Local democracy and deliberative politics. International Journal of Urban and Regional Research, 30(3), 623-637.

Baiocchi, G. (2005). Militants and citizens. Palo Alto, CA: Stanford University Press.

Baiocchi, G., \& Ganuza, E. (2014). Participatory budgeting as if emancipation mattered. Politics \& Society, 42(1), 29-50. https://doi.org/10.1177/0032329213512978

Bajpai, R. (2016). Debating difference: Group rights and liberal democracy in India. New Delhi: Oxford University Press.

Bherer, L., Fernández-Martínez, J. L., Espín, P. G., \& Sánchez, M. J. (2016). The promise for democratic deepening: The effects of participatory processes in the interaction between civil society and local governments. Journal of Civil Society, 12(3), 344-363. https://doi.org/10.1080/17448689.2016.1215957

Cabannes, Y., \& Lipietz, B. (2018). Revisiting the democratic promise of participatory budgeting in light of competing political, good governance and technocratic logics. Environment and Urbanization, 30(1), 67-84. https://doi.org/10.1177/0956247817746279

Chen, J. (2007). Canyu shi yusuan de lilun yu shijian [Theory and practice of participatory budgeting]. Jingji shehui tizhi bijiao, 130(20), 52-57.

Chowdhury, A. (2019). Anti-corruption movement: A story of the making of the Aam Admi Party and the interplay of political representation in India. Politics and Governance, 7(3), 189-198.

Eckstein, H. (2009). Case study and theory in political science. In R. Gomm, M. Hammersley, \& P. Foster (Eds.), Case study method (pp. 118-164). https://doi.org/ 10.4135/9780857024367.d11

Fewsmith, J. (2013). The logic and limits of political reform in China. Cambridge: Cambridge University Press.

Fischer, F. (2012). Participatory governance: From theory to practice. In D. Levi-Faur (Ed.), The Oxford handbook of governance. Oxford: Oxford University Press. https://doi.org/10.1093/oxfordhb/ 9780199560530.013 .0032

Fishkin, J., He, B., Luskin, R., \& Siu, A. (2010). Deliberative democracy in an unlikely place: Deliberative polling in China. British Journal of Political Science, 40(2), 435-448.

Frenkiel, E., \& Shpakovskaya, A. (2019). The evolution of representative claim-making by the Chinese Communist Party: From Mao to Xi (1949-2019). Politics and Governance, 7(3), 208-219.

Goetz, A.-M., \& Jenkins, R. (2005). Reinventing accountability: Making democracy work for the poor. London: Palgrave Macmillan.

Hayat, S., Péneau, C., \& Sintomer, Y. (2018). La représentation-incarnation. [Embodiment representation] Raisons Politiques, 72(4), 5-19.
He, B. (2011). Civic engagement through participatory budgeting in China: Three different logics at work. Public Administration And Development, 31(2), 122-133.

He, B., \& Thogersen, S. (2010). Giving the people a voice? Experiments with consultative authoritarian institutions in China. Journal of Contemporary China, 16(66), 675-692.

Heller, P., \& Isaac, T. M. T. (2003). Democracy and development: Decentralized planning in Kerala. In A. Fung \& E. O. Wright (Ed.), Deepening democracy. Institutional innovations in empowered participatory governance (pp. 77-110). London and New York, NY: Verso.

Houtzager, P. P., \& Gurza Lavalle, A. (2009). Participatory governance and the challenge of assumed representation in Brazil. IDS Working $\mathrm{Pa}$ pers, 2009(321), 1-32. https://doi.org/10.1111/j. 2040-0209.2009.00321_2.x

Jayal, N. (2016). Representing India: ethnic diversity and the governance of public institutions (1st ed.). Basingstoke: Palgrave Macmillan.

Li, F. (2005). Xinhe shiyan yu gonggong yusuan gaige yemian gongneng [The Xinhe experiment and a glimpse at public budget reform]. Zhejiang Renda, 12(6).

Ma, J. (2009), The dilemma of developing financial accountability without election: A study of China's recent budget reforms. The Australian Journal of Public Administration, 68(1), 62-72.

Ming, Z. (2014). Participatory budgeting, rural public services and pilot local democracy reform. Field Actions Science Reports, 2014(11), 1-6.

Montambeault, F. (2016). Participatory citizenship in the making? The multiple citizenship trajectories of participatory budgeting participants in Brazil. Journal of Civil Society, 12(3), 282-298. https://doi.org/10. 1080/17448689.2016.1213508

Näsström, S. (2011). Where is the representative turn going? European Journal of Political Theory, 10(4), 501-510. https://doi.org/10.1177/ 1474885111417783

Nez, H. (2016). Does participation mean reciprocal learning? The relationships between diverse stakeholders during participatory budgeting in Paris. Journal of Civil Society, 12(3), 266-281. https://doi.org/10. 1080/17448689.2016.1215371

Pitkin, H. F. (1967). The concept of representation. Berkeley, CA: University of California Press.

Rao, K. (2016). Delhi's Mohalla Sabhas: Participation and party building (A study of the participatory self-governance process initiated by the Aam Aadmi Party) (Doctoral dissertation). Centre for Urban Policy and Governance, Tata Institute of Social Sciences, Mumbai, India.

Santos, B. S. (1998). Participatory budgeting in Porto Alegre: Toward a redistributive democracy. Politics \& Society, 26(4), 461-510.

Saward, M. (2006). The representative claim. Contempo- 
rary Political Theory, 5(3), 297-318. https://doi.org/ $10.1057 /$ palgrave.cpt.9300234

Saward, M. (2010). The representative claim. Oxford: Oxford University Press.

Shah, A. (Ed.). (2007). Participatory budgeting. Washington, DC: The World Bank Institute.

Shani, O. (2018). How India became democratic: Citizenship and the making of the universal franchise. New York, NY: Penguin Viking.

Sintomer, Y. (2013). The meaning of representation: Uses and misuses of a notion. Raisons Politiques, 2(50), 13-34.

Sintomer, Y., Herzberg, C., \& Röcke, A. (2008). Les budgets participatifs en Europe [Participatory budgeting in Europe]. Paris: La Découverte.

Sintomer, Y., Herzberg, C., \& Allegretti, G. (2013). Participatory budgeting worldwide: Updated version (Study No. 25). Bonn: ENGAGEMENT GLOBAL.

Tarrow, S. (2010). The strategy of paired comparison: Toward a theory of practice. Comparative Political Studies, 43(2), 230-259. https://doi.org/10.1177/ 0010414009350044

Tawa Lama-Rewal, S. (2018a). Public hearings as social performance: Addressing the courts, restoring citizenship. South Asia Multidisciplinary Academic Journal, 2018(17). https://doi.org/10.4000/samaj.4413

Tawa Lama-Rewal, S. (2018b). Les avatars de la participation: Formes et ambiguïtés de la démocratie participative en Inde [Avatars of participation: Forms and ambiguities of participatory democracy in India].
Vulaines-sur-Seine: Editions du Croquant.

Tawa Lama-Rewal, S. (2019). Political representation in the discourse and practices of the "Party of the Common Man" in India. Politics and Governance, 7(3), 179-188.

Tharakan, M. P. K. (2005). Historical hurdles in the course of the people's planning campaign in Kerala, India. In J. Harriss, K. Stokke, \& O. Törnquist (Eds.), Politicising democracy: The new local politics of democratisation (pp. 107-126). London: Palgrave Macmillan.

Wampler, B. (2000). A guide to participatory budgeting. Washington, DC: International Budget Project. Retrieved from http://www.internationalbudget.org/ resources/library/GPB.pdf

Wampler, B. (2007). Participatory budgeting in Brazil: Contestation, cooperation, and accountability. University Park, PA: Pennsylvania State University Press.

Wampler, B. (2012a). Participation, representation, and social justice: Using participatory governance to transform representative democracy. Polity, 44(4), 666-682. https://doi.org/10.1057/pol.2012.21

Wampler, B. (2012b). Participatory budgeting: Core principles and key impacts. Journal of Public Deliberation, 8(2), 1-13. Retrieved from https://www. publicdeliberation.net/jpd/vol8/iss2/art12

Wu, Y., \& Wang, W. (2011). The rationalization of public budgeting in China: A reflection on participatory budgeting in Wuxi. Public Finance and Management, 11(3), 262-283.

\section{About the Authors}

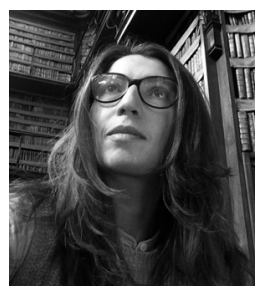

Emilie Frenkiel is an Associate Professor in Political Science at Université Paris-Est Créteil, France. She is the author of Conditional Democracy, The Intellectual Debate on Political Reform in China (ECPR, 2015). Her research interests include political representation, deliberation, political reform and participatory innovations in China. She is a member of the editorial board of social science journals La Vie des Idées and Books \& Ideas.

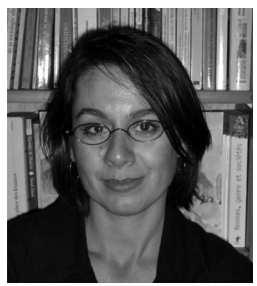

Stéphanie Tawa Lama-Rewal is a CNRS Research Fellow in Political Science who studies Indian democracy through three major themes: group (especially women's) representation; participatory experiments; and urban governance. Her recent publications include Les Avatars de la Participation en Inde. Formes et Ambiguïtés de la Démocratie Participative (Paris, Editions du Croquant, 2018) and (co-edited with Amélie Blom) Emotions and Mobilisations in South Asian Politics (Delhi, Routledge, 2019). 